\title{
Use of overburden waste for London plane (Platanus $\times$ acerifolia) growth: the role of plant growth promoting microbial consortia
}

\author{
Vera Karličić (1), \\ Danka Radić (1), \\ Jelena Jovičić-Petrović (1), \\ Blažo Lalević( ${ }^{(1)}$, \\ Filis Morina (2), \\ Vesna Golubović Curguz ${ }^{(3)}$, \\ Vera Raičević ${ }^{(1)}$
}

\begin{abstract}
Overburden waste dumps represent a huge threat to environmental quality. The reduction of their negative impact can be achieved by vegetation cover establishment. Usually, this action is complicated due to site-specific characteristics, such as nutrient deficiency, elevated metal concentration, low pH value, lack of moisture and lack of organic matter. Establishment of vegetation can be facilitated by inoculation with plant growth promoting bacteria (PGPB) which improve the physicochemical and biological properties of degraded substrates and make them more hospitable for plants. In this study we selected several strains based on the ability to produce ammonia, indole-3-acetic acid, siderophores and lytic enzymes, and to solubilize inorganic phosphates. This selection resulted in microbial consortia consisting of Serratia liquefaciens Z-I ARV, Ensifer adhaerens 10_ARV, Bacillus amyloliquefaciens D5 ARV and Pseudomonas putida P1 ARV. The effects of PGPB consortia on one-year-old London plane (Platanus $\times$ acerifolia [Aiton] Willd.) seedlings replanted into overburden waste from Kolubara Mine Basin were examined. After seven months, inoculated seedlings were $32 \%$ higher with $45 \%$ wider root collar diameter and over $80 \%$ higher total dry biomass compared to uninoculated seedlings grown in Kolubara's overburden. Inoculation resulted in higher amounts of total soluble proteins, higher chlorophyll and epidermal flavonoids content and higher total antioxidative capacity in the leaves. This study represents a successful search for effective PGPB strains and shows that microbial consortia have an important role in enhancing the growth of seedlings in nutrient deficient and degraded substrates such as overburden waste from open-pit coal mines. Positive response of London plane seedlings suggest that inoculation may help widening the opus of species for reforestation of post mining areas and speed up natural succession processes and recovery of degraded landscapes.
\end{abstract}

Keywords: Plant Growth Promoting Bacteria, London Plane, Overburden Waste, Revegetation

burden is made non-selectively, resulting in new relief forms (Ristović et al. 2010). The image of open-pits destructive character is visible only $50 \mathrm{~km}$ southwest of Belgrade (Serbia) at Kolubara Mine Basin (Lazarevac district, Serbia). Currently, at this location, mining activity occupies over 5730 ha while overburden waste dumps cover 3395 ha. Even though large areas of overburden dumps are an environmental issue, causing erosion, water and air pollution, recultiva-
(1) Faculty of Agriculture, University of Belgrade, Nemanjina 6, Zemun (Serbia); (2) Institute for Multidisciplinary Research, University of Belgrade, Kneza Višeslava 1, Belgrade (Serbia); (3) Faculty of Forestry, University of Belgrade, Kneza Višeslava 1, Belgrade (Serbia)

@ Danka Radić (danka.radic81@gmail.com)

Received: Jun 14, 2016 - Accepted: Apr 12, 2017

Citation: Karličić V, Radić D, Jovičić-Petrović J, Lalević B, Morina F, Golubović Curguz V, Raičević V (2017). Use of overburden waste for London plane (Platanus $\times$ acerifolia) growth: the role of plant growth promoting microbial consortia. iForest 10: 692-699. - doi: 10.3832/ifor2135-010 [online 2017-07-17]

Communicated by: Claudia Cocozza tion has been carried out on only 882 ha (Report on the state of environment in Branch MB Kolubara, Lazarevac - 2015).

Revegetation of overburden waste dumps is a worldwide problem, and establishment of vegetation cover on such foundations is complicated due to a numerous problems such as nutrient deficiency, elevated metal concentration, low pH value, lack of moisture, soil forming materials and of organic matter, high heterogeneity of substrate, disturbed soil hydrology and topography (Ristović et al. 2010, Karličić et al. 2016). At impoverished mine sites, enrichment with organic matter (cover crops, mulch, compost, hay) and encouragement of symbiotic relationships between plants and soil microbes makes a difference between life and death (Tredici 2007). In addition to already mentioned approaches, inoculation with plant growth promoting bacteria (PGPB) is emerging as a promising technique (Ribeiro \& Cardoso 2012, Karličić et al. 2016).

PGPB reside in the rhizosphere, root surface, and plant inner tissues (Glick 2012) and stimulate plant growth through a variety of mechanisms. PGPB directly affect 
plant growth by improving nutrient assimilation through fixation of atmospheric nitrogen, siderophores production, solubilization of phosphorus, and/or other unavailable forms of nutrients (Glick 2012). Production and/or suppression of growth regulating hormones (auxins, gibberellins, cytokinins) is another effective direct mechanism for plant growth enhancement. Indirect mechanisms include antagonism against phytopathogens, niche competition, and increased disease resistance (Glick 2012).

Plant growth promoting bacteria improve physicochemical and biological properties of poor, degraded substrates and make them more suitable for plants (Grandlic 2008, Karličić et al. 2016) with simultaneous increase of plant survival and seedling quality, especially in soils with weak microbial activity (Chanway 1997, DominguezNuñez et al. 2015). Positive outcomes of PGPB application are enhancement of seedlings emergence, faster plant growth, higher biomass production (Ribeiro \& Cardoso 2012), increase of root length, and branching, increased leaf area, and chlorophyll content, and higher resistance to abiotic stresses (Glick 2012) as well as to pests or diseases (Cawoy et al. 2014).

After more than a century of research, beneficial effects of PGPB are now exploited in agriculture, horticulture, forestry and environmental restoration (Lucy et al. 2004). Studying the interactions between PGPB and angiosperms/gymnosperms started during 1980 s and 1990s (Chanway 1997); however, up to now, the opus of tested species cover a very few genera, such as Pinus sp., Tsuga sp., Pseudotsuga sp., Quercus sp., Eucalyptus sp. etc. (Rodriguez-Barrueco et al. 1991, Ribeiro \& Cardoso 2012).

In previous attempts, Kolubara Mine landscapes were reforested with Black pine, Scots pine, European larch, European ash, Small-leaved lime, and Black locust (Karličić et al. 2016). Recultivation was mainly conducted with pioneer species, even though some of them were not the most desirable for our climate conditions (e.g., Black locust). Through their beneficial activity on soil and plants, PGPB may help widening the opus of species for reforestation of overburden areas by providing the space for more demanding ones. This assumption was tested in the present study and London plane (Platanus $\times$ acerifolia [Aiton] Willd.) was used as test plant. The ornamental values of plane trees make them a valuable part of urban landscapes all over the world. The members of Platanus spp. are well known as street trees but also are suitable for phytoremediation purposes and reforestation of post-mined land (Skousen \& Zipper 2014, Kang et al. 2016). Interestingly, even though London plane is one of the most frequent species in the public open space, so far there have been no studies dedicated to London plane PGPB interactions.

Our starting hypothesis was that the overburden waste enriched with PGPB may represent a suitable substrate for London plane growth. For this purpose the search for the most effective PGPB strains was conducted. The final confirmation of PGPB beneficial influence was obtained through in vivo experiments. Monitoring the influence on London plane growth and performances in overburden waste confirmed the success of the search.

\section{Material and methods}

\section{Collection of bacterial isolates}

Forty four isolates of soil bacteria from the Laboratory for Microbial Ecology, Faculty of Agriculture, University of Belgrade (Serbia) represented the starting point of the experiment and were tested for the presence of plant growth promoting features.

\section{Plant growth-promoting (PGP) features} Ammonia $\left(\mathrm{NH}_{3}\right)$ production was tested by growing isolates in $10 \mathrm{ml}$ peptone water. After $48-72 \mathrm{~h}$ at $28{ }^{\circ} \mathrm{C}$, Nessler's reagent $(0.5 \mathrm{ml})$ was added in each tube. Development of brown to yellow color was a positive test for ammonia production (Cappuccino \& Sherman 1992).

Assay for indoleacetic acid (IAA) production was conducted using the colorimetric method (Patten \& Glick 2002). The isolates were grown in $10 \mathrm{ml}$ of minimal salt media supplemented with $100 \mu \mathrm{g} \mathrm{ml}^{-1}$ of I-tryptophan (Sigma Aldrich, USA). Absorption was read after $48 \mathrm{~h}$ at $530 \mathrm{~nm}$ with a spectrophotometer (T70 UV/VIS Spectromer, PG Instruments LTD, UK). The amount of IAA was determined using a calibration curve of indole-3-acetic acid (Sigma Aldrich, USA) in the $1-100 \mu \mathrm{g} \mathrm{ml}^{-1}$ range.

Tab. 1 - Primer pairs used for $P C R$ amplification of gyrB gene fragments ( $R=A$ or $G ; Y=C$ or $\mathrm{T} ; \mathrm{M}=\mathrm{A}$ or $\mathrm{C} ; \mathrm{N}=$ =any).

\begin{tabular}{lll}
\hline Primers & Sequence (5'-3') & Isolate \\
\hline gyr-320 (fw) & TAARTTYGAYGAYAACTCYTAYAAAGT & Z-I ARV \\
rgyr-1260 (rv) & CMCCYTCCACCARGTAMAGTTC & (Dauga 2002) \\
UP-1E (fw) & CAGGAAACAGCTATGACCAYGSNGGNGGNAARTTYRA & 10_ARV, D5 ARV \\
modUP2r (rv) & TGTAAAACGACGGCCAGTCCRTCNACRTCNGCRTCNGTCAT & (Yamamoto et al. \\
& & 2000) \\
UP-1E (fw) & CAGGAAACAGCTATGACCAYGSNGGNGGNAARTTYRA & P1 ARV \\
APrU (rv) & TGTAAAACGACGGCCAGTGCNGGRTCYTTYTCYTGRCA & (Yamamoto et al. \\
& & 2000) \\
\hline
\end{tabular}

Siderophore production was detected on the Chrome azurol S (Fluka, USA) agar medium (Alexander \& Zuberer 1991). Chrome azurol S agar plates were spot inoculated with test organisms and incubated at $28^{\circ} \mathrm{C}$ for 48-72 h. Development of yellow-orange halo zones around colonies was considered as positive result for siderophore production.

Phosphate solubilizing activity was tested on National Botanical Research Institute's phosphate growth medium (NBRIP - Nautiyal 1999). Strains were incubated for 14 days at $30^{\circ} \mathrm{C}$, and afterwards the presence of halo zones around colonies were used to indicate their phosphate solubilization capability. P solubilization index was calculated using the following formula (eqn. 1):

$$
S I=\frac{\varnothing_{(\text {colony })}+\varnothing_{(\text {halozone })}}{\varnothing_{(\text {colony })}}
$$

Qualitative determination of lipase, $\mathrm{N}$ acetyl- $\beta$-glucosaminidase and $\beta$-glucosidase was performed by API ZYM kits according to the manufacturer's protocol (Bio Mereux, France). The API strips were inoculated with 24 -h-old cultures, and incubated at $30^{\circ} \mathrm{C}$ for $4 \mathrm{~h}$. The evaluation of the activity was carried out by comparing the colored reaction with the manufacturer's color chart. Protease production was determined using skim milk agar (Chaiharn et al. 2008). The agar plates were spot inoculated with test organisms and incubated at $30{ }^{\circ} \mathrm{C}$ for 5 days. The presence of a clear zone around the colonies indicated protease activity. The presence of cellulase was determined using carboxymethyl cellulose (CMC) agar method (Angsana et al. 2009). The agar plates were spot inoculated and incubated at $30{ }^{\circ} \mathrm{C}$ for $48 \mathrm{~h}$. Plates were flooded with $0.1 \%$ congo red solution and were destained with $1 \mathrm{M} \mathrm{NaCl}$ solution after 10 minutes. The appearance of clearing zones around colonies indicated cellulase activity.

Hydrogen cyanide ( $\mathrm{HCN}$ ) production was determined using nutrient broth amended with glycine $\left(4.4 \mathrm{~g} \mathrm{I}^{-1}\right)$. Bacteria were streaked on agar plate. Whatman filter paper no. 1 soaked in $2 \%$ sodium carbonate in $0.5 \%$ picric acid solution was placed at the top of the plate. Plates were sealed with parafilm and incubated at $28{ }^{\circ} \mathrm{C}$ for 4 days. Development of orange to red color indicated $\mathrm{HCN}$ production.

\section{Molecular identification of isolates}

Isolates that showed the most prominent plant growth promoting activities were molecularly identified by sequencing the gyrB gene. Genomic DNA was prepared by using ZR Soil Microbe DNA MiniPrep (Zymo Research, USA). The amplification of gyrB gene was performed with a thermal cycler (Kyratec, Australia, Model: SC300T) using the primer sets presented in Tab. 1 .

The reaction mixtures $(50 \mu \mathrm{l})$ contained $0.2 \mathrm{mM}$ of each dNTP (Kapa Biosystems, UK), $1 \mu \mathrm{M}$ of each primer, $0.5 \mathrm{U}$ Robust HotStart DNA Polymerase (Kapa Biosys- 
tems, UK) and $20 \mathrm{ng}$ of DNA template. PCR reactions were performed as previously described by Dauga (2002) and Yamamoto et al. (2000). PCR products were purified with QIAquick PCR Purification Kit (Qiagen, Germany), and sequenced with the primers presented in Tab. 2.

$P C R$ products were sequenced on $A B I$ 3730XL Sequencer (Macrogen Inc., Seoul, Korea) in both directions. Alignment of obtained sequences was performed using the Clustal W 2.0 algorithm and MEGA5 software. The BLAST database of National Centre for Biotechnology Information (NCBI - http://www.ncbi.nlm.nih.gov) was used to compare the sequence of bacteria with those of known bacterial species in the existing database. Sequences were deposited in the GenBank database (Accession Numbers: KT265088, KT265086, KT265087, and KT265089, for Z-I ARV, 10 ARV, D5 ARV, and P1 ARV strains, respectively).

\section{Substrates and plant material}

Substrates used for plant cultivation were Floradur $^{\circledast}$ Plant Universal (FloraGard, Germany) and overburden waste from Kolubara Basin (Serbia). Floradur ${ }^{\circledast}$ Plant Universal contained: $50 \%$ white peat, $30 \%$ black peat, and $20 \%$ compost, with $\mathrm{pH} 5.8$. Analyses of overburden were performed at the beginning of the experiment, before planting. Samples were taken from 20 different spots according to standard soil sampling principles. Obtained amount was homogenized and successive splitting by cone and quarter technique was applied. Overburden was composed of $43.2 \%$ clay, $52.7 \%$ silt, and $4.1 \%$ sand (determined with soil texture triangle according to Rowell 1994). Previous analyses of overburden waste showed neutral $\mathrm{pH}$ value, low content of nitrogen, humus (0.15\%), and of organic carbon (Karličić et al. 2016). Prior to use, overburden waste was air-dried, ground, and sieved through a $2 \mathrm{~mm}$ diameter sieve.

One-year-old bare root seedlings of Platanus $x$ acerifolia Aiton (Willd.) with mean height of $19.55 \mathrm{~cm}$ and mean collar diameter of $0.29 \mathrm{~cm}$ were obtained from the Nursery of forest and ornamental plants Vikumak (Idoš, Serbia).

\section{Microbial consortia inoculum preparation}

Inocula were prepared from four separately propagated isolates. Three bacterial strains (Serratia liquefaciens Z-I ARV, Bacillus amyloliquefaciens D5 ARV and Psedomonas putida $\mathrm{P}_{1} \mathrm{ARV}$ ) were grown in nutrient broth aerobically at $28 \pm 2{ }^{\circ} \mathrm{C} / 48 \mathrm{~h} / 100$ rpm (Biosan, Latvia). Ensifer adhaerens 10 ARV was grown in Fjodorov medium (Añderson 1958) at $28 \pm 2{ }^{\circ} \mathrm{C} / 72 \mathrm{~h} / 100$ rpm. The bacterial suspensions were centrifuged at $6000 \times \mathrm{g}$ for 10 minutes $(5804$ $\mathrm{R}$, Eppendorf, Germany) and diluted in sterile distilled water to adjust bacterial cell

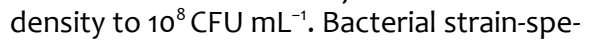
cific inocula were mixed together to form a
Tab. 2 - Primer pairs used for sequencing ( $\mathrm{R}=\mathrm{A}$ or $\mathrm{G}$; $\mathrm{Y}=\mathrm{C}$ or $\mathrm{T} ; \mathrm{M}=\mathrm{A}$ or $\mathrm{C}$ ).

\begin{tabular}{lll}
\hline Primers & Sequence (5'-3') & Isolate \\
\hline gyr-320 (fw) & TAARTTYGAYGAYAACTCYTAYAAAGT & Z-I ARV \\
rgyr-1260 (rv) & CMCCYTCCACCARGTAMAGTTC & \\
$\begin{array}{l}\text { M13R-pUC (fw) } \\
\text { M13-FP (rv) }\end{array}$ & CAGGAAACAGCTATGAC & 10_ARV, D5 ARV, P1 ARV \\
\hline
\end{tabular}

consortia inoculum in the 1:1:1:2 ratio (Serratia liquefaciens Z-I ARV: Bacillus amyloliquefaciens D5 ARV: Psedomonas putida P1 ARV: Ensifer adhaerens 10_ARV).

\section{In vivo trials}

The experiment was based on three treatments: (a) seedlings replanted into commercial substrate, Floradur ${ }^{\circledast}$ Plant Universal (FS); (b) seedlings replanted into overburden (O); (c) seedlings replanted into overburden and inoculated with PGPB consortia (OI). All seedlings were placed in $2.5 \mathrm{dm}^{3}$ volume of substrate in $3 \mathrm{dm}^{3}$ polyethylene bags during the period of dormancy. Inoculation was conducted two times, at the beginning of the growing season (March) and 12 weeks later. Each seedling in the Ol treatment received $100 \mathrm{ml}$ of inoculum prepared as described above. Seedlings in the other two treatments (FS and $O$ ) received $100 \mathrm{ml}$ of distilled water. Plants were grown until the beginning of October. The temperature conditions in Belgrade during the experiment are presented in Tab. 3. The trial was performed outdoors at a location of the Faculty of Agriculture in Belgrade (Serbia) and was arranged as a completely randomized splitplot design $(n=20$ seedlings per treatment).

\section{Plant growth measurements and leaf analyses}

Seedling height and root collar diameter were recorded two times. The first measurement was conducted 18 weeks after the first inoculation (July) and the second in October. At the end of the experimental period (October), shoot and root dry weights were also recorded. Plants from each treatment were grouped and dried at $65^{\circ} \mathrm{C}$ until constant weight.

For biochemical analyses, fully developed, green and vital mid-shoot leaves without visible signs of senescence were sampled in the beginning of October (harvest period) and ground in liquid nitrogen.

Soluble proteins were extracted in $100 \mathrm{mM}$ potassium-phosphate buffer ( $\mathrm{pH}$ 6.5) with $0.1 \%$ Triton $X-100(\mathrm{w} / \mathrm{v}), 5 \%$ insoluble polyvinylpyrrolidone (PVP) and $1 \mathrm{mM}$ phenylmethylsulfonyl fluoride (PMSF), according to Vidović et al. (2015).

Following centrifugation at $16,000 \times g$ (5415 R, Eppendorf, Germany) for $10 \mathrm{~min}$ at $4{ }^{\circ} \mathrm{C}$, protein content in the soluble fraction was determined using bovine serum albumin as standard (Bradford 1976). For determination of total soluble phenolics content, leaf samples were homogenized in liquid nitrogen and extracted in methanol with $0.1 \% \mathrm{HCl}$ (Vidović et al. 2015). Following centrifugation, the supernatants were separated and the content of total soluble phenolics was determined using the FolinCiocalteu reagent, as described by Morina et al. (2008). The concentrations of phenolics in methanolic extracts were calculated using gallic acid as a standard (Singleton \& Rossi 1965). Total antioxidative capacity of methanolic extracts was measured using 2.2'-azino-bis (3-ethylbenzothiazoline-6-sulphonic acid) ABTS assay, as described by Morina et al. (2008). For simultaneous in vivo assessment of total leaf chlorophyll and epidermal flavonoids content, optical leaf-clip meter Dualex4Scientific (Force-A, Orsay, France) was used, as described in Cerović et al. (2012).

\section{Statistical analysis}

Data were analyzed by two-way analysis of variance (ANOVA) followed by LSD tests $(p<0.05)$ and Independent Two Sample $t$ test. The analyses were conducted using the software package SPSS v. 22 (SPSS Inc., Chicago, IL, USA).

\section{Results and discussion}

Overburden waste dumps represent huge areas of unproductive land with erosion susceptibility and hazardous influence on soil, water, and air quality. These problems are usually solved through vegetation development (Ristović et al. 2010).

Tab. 3 - Daily maximum and daily minimum temperature range during the outdoor experiment (data for Belgrade, Serbia, obtained from the Hydrometeorological Service of Serbian Republic).

\begin{tabular}{lcc}
\hline Period & $\begin{array}{c}\text { Daily maximum } \\
\text { temperature range }\left({ }^{\circ} \mathrm{C}\right)\end{array}$ & $\begin{array}{c}\text { Daily minimum } \\
\text { temperature range }\left({ }^{\circ} \mathrm{C}\right)\end{array}$ \\
\hline February (dormant season) & $-0.3 \rightarrow 23.4$ & $-6.4 \rightarrow 8.8$ \\
Spring (March, April, May) & $8.4 \rightarrow 29.7$ & $1.5 \rightarrow 17.8$ \\
Summer (June, July, August) & $18.0 \rightarrow 34.8$ & $11.0 \rightarrow 22.9$ \\
September & $15.8 \rightarrow 28.3$ & $8.0 \rightarrow 20.0$ \\
\hline
\end{tabular}


Tab. 4 - Plant growth promoting attributes of isolated strains. $\left(\mathrm{NH}_{3}\right)$ : ammonia; (IAA): indoleacetic acid; (Sid): siderophores; (PSI): phosphate solubilization index; (+) presence of the feature; $(-)$ absence of the feature. $\left({ }^{*}\right)$ : selected strains.

\begin{tabular}{|c|c|c|c|c|}
\hline \multirow{2}{*}{ Isolates } & \multicolumn{3}{|c|}{ Production } & \multirow{2}{*}{ PSI } \\
\hline & $\mathrm{NH}_{3}$ & IAA $\left(\mu \mathrm{g} \mathrm{ml}^{-1}\right)$ & Sid & \\
\hline $3 \mathrm{~N}$ ARV & - & $1.7 \pm 0.3$ & + & - \\
\hline 6N ARV & + & $0.4 \pm 0.1$ & - & - \\
\hline 7N ARV & + & $0.8 \pm 0.1$ & - & $2.33 \pm 0.45$ \\
\hline $8 \mathrm{~N} A R V$ & + & $0.8 \pm 0.2$ & - & - \\
\hline $15 N$ ARV & + & $0.4 \pm 0.1$ & - & - \\
\hline 19 D ARV & + & $0.5 \pm 0.02$ & - & - \\
\hline Z-I1 ARV & + & $9.6 \pm 0.2$ & + & $2.25 \pm 0.32$ \\
\hline Z-I ARV & + & $8.4 \pm 0.3$ & + & $2.60 \pm 0.30$ \\
\hline Z-H ARV & + & $0.5 \pm 0.1$ & - & - \\
\hline CSP ARV & - & $2.6 \pm 0.3$ & - & - \\
\hline G1SP ARV & + & $2.0 \pm 0.2$ & - & - \\
\hline GSP ARV & - & $1.8 \pm 0.3$ & - & - \\
\hline 2TSB ARV & + & $0.8 \pm 0.1$ & - & - \\
\hline O3 ARV & + & $1.1 \pm 0.2$ & - & - \\
\hline 2T ARV & + & $10.5 \pm 0.5$ & - & - \\
\hline F ARV & + & $0.4 \pm 0.1$ & - & - \\
\hline 333 ARV & - & $26.4 \pm 0.5$ & + & $2.11 \pm 0.22$ \\
\hline 10_ARV* & + & $44.5 \pm 0.5$ & + & $2.33 \pm 0.30$ \\
\hline NV1 ARV & + & $4.0 \pm 0.2$ & - & $2.11 \pm 0.25$ \\
\hline NV2 ARV & + & $5.6 \pm 0.4$ & + & - \\
\hline NV3 ARV & + & $3.8 \pm 0.4$ & + & $2.14 \pm 0.15$ \\
\hline NV4 ARV & + & $4.0 \pm 0.3$ & + & - \\
\hline NV5 ARV & + & $8.0 \pm 0.4$ & - & $1.50 \pm 0.15$ \\
\hline NV6 ARV & + & $2.4 \pm 0.3$ & - & - \\
\hline NV7 ARV & + & $1.1 \pm 0.2$ & - & - \\
\hline 4 ARV & + & $1.4 \pm 0.2$ & - & - \\
\hline $8 \mathrm{ARV}$ & + & $0.4 \pm 0.1$ & - & $2.22 \pm 0.25$ \\
\hline D1 ARV & + & $0.8 \pm 0.1$ & - & - \\
\hline D2 ARV & + & $1.1 \pm 0.15$ & - & - \\
\hline D3 ARV & + & $0.5 \pm 0.1$ & - & $2.27 \pm 0.28$ \\
\hline D5 ARV* & + & $1.5 \pm 0.3$ & + & - \\
\hline D6 ARV & + & $1.8 \pm 0.2$ & - & - \\
\hline P1 ARV* & + & $1.2 \pm 0.1$ & + & $2.70 \pm 0.25$ \\
\hline T1 ARV & - & $1.4 \pm 0.1$ & - & - \\
\hline T6 ARV & + & $4.0 \pm 0.2$ & + & - \\
\hline T10 ARV & - & $1.4 \pm 0.3$ & - & $2.50 \pm 0.30$ \\
\hline
\end{tabular}

One of the promising ways for raising the effectiveness of overburden revitalization is the application of PGPB, and this has been successfully achieved in the present study. After series of biochemical tests, isolates with the most prominent PGP features were identified as Serratia liquefaciens Z-I ARV (KT265088), Ensifer adhaerens 10_ARV (KT265086), Bacillus amyloliquefaciens D5 ARV (KT265087) and Psedomonas putida P1 ARV (KT265089). These four strains were selected from the collection of 44 soil isolates which were tested for the presence of the most frequent PGPB features (Tab. 4).

The results of biochemical test have shown that $\mathrm{NH}_{3}$ was produced by 33 isolates (75\%), whereas 36 isolates (82\%) were characterized as IAA producers. Such results were expected since these two features are usual among beneficial soil bacteria (Gamalero \& Glick 2011). The results of IAA production distinguished Ensifer adhaerens 10_ARV which produced considerably higher amounts compared to others
(44.5 $\mu \mathrm{g} \mathrm{ml}^{-1}$ ). Similar findings on E. adhaerens have been noted by Kaur et al. (2014). Indole-3-acetic acid is the most common form of auxins (Gamalero \& Glick 2011) which affect plant cell division, extension, and differentiation, increase the rate of root development and nodulation, initiate lateral and adventitious root formation and stimulate seed and tuber germination. Metabolic processes such as photosynthesis, biosynthesis of various metabolites, and resistance to stressful conditions are modulated by auxins (Glick 2012). Accordingly, IAA indirectly increases water and nutrient supplies leading to higher root exudation and biomass production (Gamalero \& Glick 2011, Glick 2012).

The production of siderophores was expressed by 11 isolates. This characteristic of PGPB is very important since the amount of available iron in soil is limited (Gamalero \& Glick 2011). To survive with a restricted supply of iron, bacteria produce low-molecular weight compounds (siderophores) with high affinity for $\mathrm{Fe}^{+3}$ (Gamalero \& Glick
2011). PGPB siderophores raise Fe supply to plants and lower down the Fe amounts available for plant pathogens (Gamalero \& Glick 2011). In addition, siderophores form stable complexes with $\mathrm{Al}, \mathrm{Cd}, \mathrm{Cu}, \mathrm{Ga}, \mathrm{In}, \mathrm{Pb}$ and $\mathrm{Zn}$ and are important for reducing the level of plant stress caused by high concentration of heavy metals (Gamalero \& Glick 2011).

Solubilization of phosphates is another crucial feature of PGPB which provides more $\mathrm{H}_{2} \mathrm{PO}_{4}{ }^{-}$and $\mathrm{HPO}_{4}{ }^{2-}$ for plants (Gamalero \& Glick 2011). Slightly higher number of isolates showed positive result in phosphate solubilization testing $(27 \%)$ compared to siderophores production. Serratia liquefaciens Z-I ARV and Pseudomonas putida $\mathrm{P} 1 \mathrm{ARV}$ expressed the highest $\mathrm{P}$ solubilization ability. Ensifer adhaerens 10_ARV was also capable to solubilize inorganic phosphates (Tab. 4). This characteristic was already recorded among other representatives of these three bacterial species (Jha et al. 2009, Singh \& Prakash 2012, Kaur et al. 2014).

Platanus $\times$ acerifolia is very tolerant to numerous abiotic stresses such as limited root space, unfavourable soil conditions, drought, air pollution, urban climate (Mimet et al. 2009) and exhibits high accumulation capacity of heavy metals (Ivanová et al. 2007, Kang et al. 2016). Those features make plane trees suitable for urban, surface mine areas (Skousen \& Zipper 2014) and phytoremediation activities (Kang et al. 2016). On the other side, a number of pests and pathogens can threaten this genus causing considerable damage. Some of the most destructive are canker stain caused by Ceratocystis fimbriata Ell.et. Halsted f.sp. platani, anthracnose by Apiognomonia veneta (Sacc. et Speg.), Hohn, powdery mildew by Microsphera platani (Howe) and trunk rot by Phytophthora cinnamomi Rands (Pilotti et al. 2014). Considering the prevalence of plane trees in urban areas all over the world it is important to develop suitable measures to prevent or restrict the pathogens. However, up to now, the application of phytosanitary measures, chemical treatments and biological control measures were not particularly efficient (Panconesi 1999, Pilotti et al. 2015). A genetic approach with the aim of selecting resistant plane genotypes is believed to be an effective way of disease control (Pilotti et al. 2015). Breeding programs with American sycamore (Platanus occidentalis L.) and oriental plane tree (Platanus orientalis L.) resulted in cultivars "Columbia" and "Liberty", which are highly resistant to Apiognomonia veneta (Sacc. et Speg.), Hohn (Kowalski 2013). In addition, Vigouroux \& Olivier (2004) and Pilotti et al. (2009) produced genotypes resistant to Ceratocystis fimbriata Ell.et. Halsted f.sp. platan.

However, the selection for resistant genotypes is very extensive while large-scale usage of a small number of clones can be detrimental for plane trees biodiversity ( $\mathrm{Pi}$ lotti et al. 2015). This emphasizes the need 
for more intensive selection activities and new approaches which may include biological control. PGPB with biocontrol features already represent an effective measure against numerous plant pathogens (Glick 2012, Cawoy et al. 2014). The mechanisms employed by biocontrol bacteria are diverse and include antibiotics, siderophores and lytic enzymes production which are all effective against Botrytis cinerea, Fusarium spp., Phytophthora spp., Rhizoctonia solani, Pythium ultimum, etc. (Glick 2012). PGPB are also capable to activate induced systemic resistance (ISR), and prepare plant defense mechanisms for potential pathogen attack. ISR is not pathogenspecific and it can effectively suppress diseases caused by different plant pathogens (Glick 2012). All those mechanisms secure wide spectra of PGPB action. Combination of resistant genotypes or genotypes with certain level of resistance with PGPB may represent a new approach in reducing the incidence or severity of plane diseases. Also, PGPB with biocontrol function can be applied through soil introduction or foliar application which is effective for suppression of foliar diseases (Meena 2014). Genetic manipulation with potentially effective biocontrol agent may result in superior biocontrol strains, and offer even more promising results (Gamalero \& Glick 2011).

In our study, the biocontrol potential of the isolates was estimated trough production of several lytic enzymes (lipase, $\mathrm{N}$-acetyl- $\beta$-glucosaminidase, $\beta$-glucosidase, protease, cellulase), which are capable of damaging fungal cell-walls (Glick 2012, Cawoy et al. 2014). These tests revealed that only ten isolates produce substances which are known to have antifungal activity (Tab. 5). Serratia liquefaciens Z-I ARV, Pseudomonas putida P1 ARV and Bacillus amyloliquefaciens D5 ARV were capable to produce lytic enzymes. These species have already been recognized as effective biocontrol agents (Whiteman \& Stewart 1998, Cawoy et al. 2014, Sharma et al. 2014). The only isolate that stood up after screening of PGP direct mechanisms but did not express any indirect mechanism was Ensifer adhaerens 10 ARV.

New tendencies in bacterial inoculum application emphasize the ecological advantages of mixed populations over single strain inocula (Gamalero \& Glick 2011). After series of in vitro tests, inoculum consisting of Serratia liquefaciens Z-I ARV, Ensifer adhaerens 10_ARV, Bacillus amyloliquefaciens D5 ARV and Pseudomonas putida P1 ARV was used for in vivo experiments aimed at confirming the PGPB potential of selected isolates under field conditions. $S$. liquefaciens Z-I ARV was selected based on high $\mathrm{P}$ solubilization index and the ability to perform all four direct mechanisms and produce several lytic enzymes. E. adhaerens 10_ARV showed the highest IAA production. B. amyloliquefaciens D5 ARV showed ability to use several direct mechanisms and was the only isolate that pro-

Tab. 5 - The presence of lytic enzymes. $(\mathrm{Na} \beta)$ : $\mathrm{N}$-acetyl $\beta$-glucosaminidase; $(\beta$-glu): $\beta$ glucosidase; $(\mathrm{HCN})$ : hydrogen cyanide; $(+)$ presence of the feature; $(-)$ absence of the feature; $\left(^{*}\right)$ : selected strains.

\begin{tabular}{|c|c|c|c|c|c|}
\hline \multirow{2}{*}{ Isolates } & \multicolumn{5}{|c|}{ Lytic enzymes } \\
\hline & lipase & $\mathrm{Na} \beta$ & $\beta$-glu & protease & cellulase \\
\hline 7N ARV & - & - & - & + & - \\
\hline Z-I ARV* & + & + & + & + & - \\
\hline G1SP ARV & - & + & - & - & - \\
\hline 333 ARV & + & + & + & + & - \\
\hline NV4 ARV & - & - & - & + & - \\
\hline NV5 ARV & - & - & - & + & - \\
\hline $7 \mathrm{ARV}$ & + & - & - & - & - \\
\hline D5 ARV* & - & - & - & + & + \\
\hline D6 ARV & + & - & - & - & - \\
\hline P1 ARV* & - & + & + & - & - \\
\hline
\end{tabular}

Tab. 6 - The height and root collar diameter of Platanus $\times$ acerifolia seedlings. (OI): seedlings re-planted into overburden and inoculated with PGPB consortia; (O): seedlings re-planted into overburden; (FS): seedlings re-planted into commercial substrate (Floradur ${ }^{\circledast}$ Plant Universal). The first measurement was in July, and the second measurement was in October. Mean values and standard errors $(n=20)$ are reported. Values in the same column with different letters differ significantly $(p<0.05)$ according to the LSD test.

\begin{tabular}{|c|c|c|c|c|c|c|}
\hline \multirow{2}{*}{$\begin{array}{l}\text { Treat- } \\
\text { ment }\end{array}$} & \multicolumn{3}{|c|}{ Seedling height $(\mathrm{cm})$} & \multicolumn{3}{|c|}{ Root collar diameter $(\mathrm{cm})$} \\
\hline & Start & $1^{\text {st }}$ meas. & $2^{\text {nd }}$ meas. & Start & $1^{\text {st }}$ meas. & $2^{\text {nd }}$ meas. \\
\hline Ol & $19.98 \pm 4.31^{\mathrm{a}}$ & $37.00 \pm 5.11^{\mathrm{b}}$ & $42.60 \pm 4.88^{b}$ & $0.30 \pm 0.05^{\mathrm{a}}$ & $0.57 \pm 0.07^{\mathrm{b}}$ & $0.68 \pm 0.07^{b}$ \\
\hline 0 & $19.33 \pm 3.55^{\mathrm{a}}$ & $28.43 \pm 5.03^{a}$ & $32.33 \pm 4.65^{a}$ & $0.27 \pm 0.07^{a}$ & $0.40 \pm 0.08^{\mathrm{a}}$ & $0.47 \pm 0.08^{\mathrm{a}}$ \\
\hline FS & $19.35 \pm 4.12^{\mathrm{a}}$ & $39.55 \pm 6.05^{b}$ & $47.43 \pm 5.98^{c}$ & $0.30 \pm 0.04^{\mathrm{a}}$ & $0.71 \pm 0.15^{c}$ & $0.77 \pm 0.13^{c}$ \\
\hline $\mathrm{LSD}_{0.05}$ & & 3.105 & & & 0.056 & \\
\hline
\end{tabular}

Tab. 7 - Roots and shoots dry biomasses of Platanus $\times$ acerifolia seedlings. (OI): seedlings re-planted into overburden and inoculated with PGPB consortia; (O): seedlings re-planted into overburden; (FS): seedlings re-planted into commercial substrate (Floradur ${ }^{\circledR}$ Plant Universal); RDB: root dry biomass; SDB: shoot dry biomass. Mean values and standard errors $(n=20)$ are reported. Values in the same column with different letters differ significantly $(p<0.05)$ according to the LSD test.

\begin{tabular}{lcc}
\hline Treatment & RDB $(\mathbf{g})$ & SDB $(\mathbf{g})$ \\
\hline Ol & $2.35 \pm 0.94^{\mathrm{b}}$ & $4.34 \pm 0.65^{\mathrm{b}}$ \\
$\mathrm{O}$ & $1.23 \pm 0.91^{\mathrm{a}}$ & $2.47 \pm 0.98^{\mathrm{a}}$ \\
$\mathrm{FS}$ & $3.73 \pm 2.69^{\mathrm{c}}$ & $7.28 \pm 3.46^{\mathrm{c}}$ \\
\hline LSD $_{0.05}$ & 1.091 & 1.336 \\
\hline
\end{tabular}

duced cellulase. P. putida P1 ARV stood up with the highest $P$ solubilization index among tested isolates.

Plant-bacteria interactions are under strong influence of abiotic factors and indigenous microflora. Those two factors are the most common cause of PGPB failure in uncontrolled environment (Karličić et al. 2016) and in vivo testing is crucial for proper assessment of PGPB potential.

The effects of applied treatments on height and root collar diameter are presented in Tab. 6. At the start of the experiment, the seedlings had similar features (height and root collar diameter). After 12 weeks inoculated seedlings (OI) had similar height to those grown in the commercial substrate (FS), but were significantly higher compared to uninoculated overburden seedlings $(\mathrm{O})$. At the end of the experiment the FS seedlings showed the highest growth increment, followed by Ol seed- lings, while $O$ treatment seedlings were the smallest. Comparison of overburden seedlings revealed positive effect of inoculation on height increment.

Measurements of root collar diameter conducted in July put the treatments in the following order, $\mathrm{FS}>\mathrm{Ol}>\mathrm{O}$ and this trend was maintained until the end of the experiment. In addition, positive effect of inoculation on seedlings width was observed when comparing $\mathrm{OI}$ and $\mathrm{O}$ treatments.

At the end of the experiment, seedlings were uprooted; roots and shoots were separated and dried until constant weight. Tab. 7 shows roots and shoots dry biomass of Platanus $\times$ acerifolia seedlings. The highest biomass production was noted in FS treatment. The OI treatment was intermediate as it yielded significantly higher root and shoot biomass than the $\mathrm{O}$ treatment, suggesting that inoculation had a positive influence on seedlings biomass production. 
Tab. 8 - Fitness condition of Platanus $\times$ acerifolia overburden seedlings. (OI): seedlings re-planted into overburden and inoculated with PGPB consortia; (O): seedlings replanted into overburden. Mean values and standard errors $(n=12)$ are reported. Different letters in the same column indicate significant differences $(p<0.05)$ after Independent Two Sample t-test.

\begin{tabular}{lccccc}
\hline $\begin{array}{l}\text { Treat- } \\
\text { ment }\end{array}$ & $\begin{array}{c}\Sigma \text { proteins } \\
\left(\mathrm{mg} \mathrm{gFW}^{-1}\right)\end{array}$ & $\begin{array}{c}\Sigma \text { phenolics } \mu \mathrm{mol} \\
\text { gallic acid eq. } \\
\left(\mathrm{gFW}^{-1}\right)\end{array}$ & $\begin{array}{c}\Sigma \text { chlorophyll } \\
\left(\mathrm{mg} \mathrm{cm}^{-2}\right)\end{array}$ & $\begin{array}{c}\Sigma \text { antioxidative } \\
\text { capacity } \mu \mathrm{mol} \\
\text { ascorbate eq. } \\
\left(\mathrm{gFW}^{-1}\right)\end{array}$ & $\begin{array}{c}\text { epidermal } \\
\text { flavonoids } \\
\left(\mathrm{g} \mathrm{cm}^{-2}\right)\end{array}$ \\
\hline Ol & $1.41 \pm 0.32^{\mathrm{b}}$ & $119.03 \pm 9.69^{\mathrm{a}}$ & $16.6 \pm 1.06^{\mathrm{b}}$ & $10.09 \pm 2.01^{\mathrm{b}}$ & $1.13 \pm 0.161^{\mathrm{b}}$ \\
$\mathrm{O}$ & $0.94 \pm 0.11^{\mathrm{a}}$ & $105.88 \pm 13.07^{\mathrm{a}}$ & $13.9 \pm 0.94^{\mathrm{a}}$ & $4.93 \pm 1.10^{\mathrm{a}}$ & $0.38 \pm 0.286^{\mathrm{a}}$ \\
\hline
\end{tabular}

Comparison of inoculated and uninoculated overburden seedlings revealed positive effects of PGPB consortia on plant performances (Tab. 6, Tab. 7). Egamberdiyeva (2007) claimed that poor substrates are more suitable for exhibiting the full potential of PGPB, while in rich substrates plants are already well supplied. In our in vivo test one third of the seedlings were grown in commercial substrate with the aim of comparing performances of inoculated seedlings to those grown in nutrient sufficient substrate. At the end of the experiment, even though applied PGPB consortia enhanced London plane growth, their effects were not strong enough to parry seedlings grown in commercial substrate, suggesting that inoculation can compensate the lack of nutrients, but to a certain extent (Tab. 6 , Tab. 7).

Seedlings grown in FS were 10\% higher with $12 \%$ wider root collar diameter, $40 \%$ higher shoot dry biomass and 37\% higher root dry biomass in comparison to OI seedlings. On the other hand, comparison of uninoculated and inoculated overburden seedlings showed that the presence of PGPB caused $32 \%$ increase in seedling height, $45 \%$ wider root collar diameter, $76 \%$ increase of shoot dry biomass and $91 \%$ of root dry biomass (Tab. 6, Tab. 7). Similar results were reported by Karlidag et al. (2007) where inoculation with Bacillus sp. and Microbacterium sp. induced $30 \%$ increase of apple shoot length. RodriguezBarrueco et al. (1991) reported 90\% increment of oak seedlings biomass after inoculation with Azospirillum brasilense, while Mesorhizobium sp. increased White birch biomass by $60 \%$ (Sousa et al. 2015). Moreover, we have previously reported that inoculation with Azotobacter chroococcum and several Bacillus sp. strains resulted with 34\% higher root dry biomass of Scots pine and $23 \%$ of Norway spruce seedlings (Karličić et al. 2016).

The data on PGPB effects on plant morphology are voluminous, and recent studies are more interested in physiological aspects of inoculation. In this manner efforts are directed towards revealing PGPB influences on mineral content of plants, chlorophyll content, and accumulation of secondary metabolites (Rojas-Tapias et al. 2012). At the end of our experiment, fitness condition of Platanus $x$ acerifolia inoculated and uninoculated overburden seedlings were estimated through the content of total soluble proteins, total soluble phenolics, total chlorophyll, and several other parameters (Tab. 8). A significant influence of applied consortia on total soluble proteins content, chlorophyll content, total antioxidative capacity, and epidermal flavonoids content has been revealed. On the other hand, inoculation did not affect the total soluble phenolics content. Increase of leaf chlorophyll content, amount of total proteins, together with higher shoot growth and total dry matter, indicate an enhanced nutrient assimilation, as similarly observed by Mia et al. (2010). Increased total antioxidative capacity in OI treatment compared to $O$ seedlings may be of great importance for stress amelioration (RojasTapias et al. 2012), especially considering that the seedlings are intended for harsh environments, such as overburden waste dumps. Successful adaptation and growth of plants in inhospitable environments highly depends on species choice, seedling quality (Karličić et al. 2016), and the ability to recover the damaged root system shortly after replanting. The most critical moment is replanting from nurseries to final place. At this point, the presence of PGPB can be of great help considering their influence on transplant shock mitigation (Kloepper et al. 2004). Rapid development of new roots, increase of root growth, length and weight are commonly reported responses in trees to PGP bacteria inoculations (Karlidag et al. 2007, Sousa et al. 2015). These effects has also been confirmed in the present study where inoculation caused $91 \%$ increase of root dry biomass (Tab. 7), presumably by modulating endogenous plant mechanisms which regulate root development (Ribeiro \& Cardoso 2012).

Literature data emphasize the validity of PGPB inoculation in revegetation projects of anthropogenically devastated areas. This has been further confirmed by the results obtained in the present study. All benefits that PGPB inoculation provides to London plane seedlings may be of great help in alleviating overburden waste dumps challenges. Also, such effects may be crucial for trees in urban areas considering their constant exposure to numerous stresses (Calfapietra et al. 2015). The main issue is finding the suitable bacteria strains that will be capable to express their beneficial effects in uncontrolled conditions. Considering the obtained results, our search has been successful, and the presence of the PGPB consortia in overburden waste raised its suitability for plant growth. Positive response of London plane seedlings suggests that inoculation may help widening the opus of species for reforestation of post-mining areas. This may be the proper measure that opens the door for more demanding species and speeds up natural succession processes and recovery of degraded landscapes.

\section{Conclusion}

PGPB used in our study were selected based on their PGP mechanisms. In vivo experiments with PGPB consortia confirmed their plant growth promoting nature through stimulating effects on London plane height, root collar diameter, total biomass production, and fitness. This study justifies the PGPB inoculation as a proper technique in mitigation of overburden waste dumps issues.

\section{Acknowledgments}

This work was supported by the Ministry of Education, Science and Technological Development of the Republic of Serbia, Grant No. TR 31080.

\section{References}

Alexander DB, Zuberer DA (1991). Use of chrome azurol $S$ reagents to evaluate siderophore production by rhizosphere bacteria. Biology and Fertility of Soils 12: 39-45. - doi: 10.1007/BFoo 369386

Anderson GR (1958). Ecology of Azotobacter in soils of the Palouse region: I. Occurrence. Soil Science 86: 57-62. - doi: 10.1097/00010694-1958 08000-00001

Angsana R, Warinthorn S, Annop N, Pawinee C (2009). Combination effect of $\mathrm{pH}$ and acetate on enzymatic cellulose hydrolysis. Journal of Environmental Sciences 21: 965-970. - doi: 10.1016/S1001-0742(08)62369-4

Bradford M (1976). A rapid and sensitive method for the quantitation of microgram quantities of protein utilizing the principle of protein-dye binding. Analytical Biochemistry 72: 248-254. doi: 10.1016/0003-2697(76)90527-3

Calfapietra C, Peñuelas J, Niinemets T (2015). Urban plant physiology: adaptation-mitigation strategies under permanent stress. Trends in Plant Science 20: 72-75. - doi: 10.1016/j.tplants. 2014.11.001

Cappuccino JC, Sherman N (1992). Microbiology: a laboratory manual. Benjamin/Cummings Publishing Company, New York, USA, pp. 544.

Cawoy H, Debois D, Franzil L, Pauw ED, Thonart $P$, Ongena M (2014). Lipopeptides as main ingredients for inhibition of fungal phytopathogens by Bacillus subtilis/amyloliquefaciens. Microbial Biotechnology 8: 281-295. - doi: 10.1111 /1751-7915.12238

Cerović ZG, Masdoumier G, Ghozlen NB, Latouche $G$ (2012). A new optical leaf-clip meter for simultaneous non-destructive assessment 
of leaf chlorophyll and epidermal flavonoids. Physiologia Plantarum 146: 251-260. - doi: 10.1111 /j.1399-3054.2012.01639.x

Chaiharn M, Chunhaleuchanon S, Kozo A, Lumyong $S$ (2008). Screening of rhizobacteria for their plant growth promoting activities. KMITL Science and Technology Journal 8: 18-23. [online] URL: http://www.thaiscience.info/jour nals/Article/KLST/10424521.pdf

Chanway CP (1997). Inoculation of tree roots with plant growth promoting soil bacteria: an emerging technology for reforestation. Forest Science 43: 99-112. [online] URL: http://www. ingentaconnect.com/content/saf/fs/1997/0000 0043/00000001/art00013

Dauga C (2002). Evolution of the gyrB gene and the molecular phylogeny of Enterobacteriaceae: a model molecule for molecular systematic studies. International Journal of Systematic and Evolutionary Microbiology 52: 531-547.

doi: 10.1099/00207713-52-2-531

Dominguez-Nuñez JA, Medina M, Berrocal-Lobo M, Anriquez A, Albanesi A (2015). The combined effects of Pseudomonas fluorescens CECT 844 and the black truffle co-inoculation on Pinus nigra seedlings. iForest - Biogeosciences and Forestry 8: 624-630. - doi: 10.3832/ifor1334007

Egamberdiyeva E (2007). The effect of plant growth promoting bacteria on growth and nutrient uptake of maize in two different soils. Applied Soil Ecology 36: 184-189. - doi: 10.1016/ j.apsoil.2007.02.005

Gamalero E, Glick BR (2011). Mechanisms used by plant growth-promoting bacteria. In: "Bacteria in Agrobiology: Plant Nutrient Management" (Maheshwari DK ed). Springer-Verlag, BerlinHeidelberg, Germany, pp. 17-46. - doi: 10.1007/9 78-3-642-21061-7_2

Glick BR (2012). Plant growth-promoting bacteria: mechanisms and applications. Scientifica 115. - doi: 10.6064/2012/963401

Grandlic CJ (2008). Plant growth-promoting bacteria suitable for the phytostabilization of mine tailings. PhD thesis, Department of Soil, Water and Environmental Science, University of Arizona, Tucson, AZ, USA, pp. 227. [online] URL: http://search.proquest.com/openview/d5c5d88 2dd035e72b4eo8aa2fe988aab/1

Ivanová H, Bernadovičová S, Pastirčáková K (2007). Influence of changed ecological conditions on occurrence of London plane (Platanus × hispanica Münchh.) anthracnose. Folia Oecologica 34: 1-8. [online] URL: http://search.pro quest.com/openview/3ob16a716fge19103933a4 $55656 \mathrm{c} 79 \mathrm{c2} / 1$

Jha BK, Pragash MG, Cletus J, Raman G, Sakthivel N (2009). Simultaneous phosphate solubilization potential and antifungal activity of new fluorescent pseudomonad strains, Pseudomonas aeruginosa, P. plecoglossicida and $P$. mosselii. World Journal of Microbiology and Biotechnology 25: 573-581. - doi: 10.1007/s11274oo8-9925-x

Kang W, Bao J, Zheng J, Xu F, Wang L (2016). Potential of woody plants from a Tonglushan ancient copper spoil heap for phytoremediation of heavy metal contaminated soil. International Journal of Phytoremediation 25. - doi: 10.1080/15226514.2014.950412

Karličić V, Golubović Curguz V, Raičević V (2016).
The alleviation of reforestation challenges by beneficial soil microorganisms. Reforesta 1: 238-260. [online] URL: http://scindeks.ceon.rs/ article.aspx?artid=2466-43671601238K

Karlidag H, Esitken A, Turan M, Sahin F (2007). Effects of root inoculation of plant growth promoting rhizobacteria (PGPR) on yield, growth and nutrient element contents of leaves of apple. Scientia Horticulturae 114: 16-20. - doi: 10.1016/j.scienta.2007.04.013

Kaur H, Sharma P, Kaur N, Gill BS (2014). Tapping of native Bradyrhizobium and Ensifer sp. diversity for functional traits in soybean (Glycine $\max ($ L.) Merrill). Legume Research 37: 651-657. doi: 10.5958/0976-0571.2014.00691.2

Kloepper JW, Reddy MS, Rodríguez-Kabana R, Kenney DS, Kokalis-Burelle N, Martinez-Ochoa $\mathrm{N}$ (2004). Application for rhizobacteria in transplant production and yield enhancement. Acta Horticulturae 631: 219-229. - doi: 10.17660/Acta Hortic.2004.631.28

Kowalski T (2013). Foliar diseases of broadleaved trees. In: "Infectious Forest Diseases" (Gonthier P, Nicolotti $G$ eds). CAB International, Wallingford, UK, pp. 488-518.

Lucy M, Reed E, Glick BR (2004). Applications of free living plant growth-promoting rhizobacteria. Antonie van Leeuwenhoek 86: 1-25. - doi: 10.1023/B:ANTO.0000024903.10757.6e

Meena B (2014). Biological control of pest and diseases using fluorescent Pseudomonads. In: "Basic and Applied Aspects of Biopesticides" (Sahayaraj K ed). Springer, Dehli, India, pp. 1730. - doi: 10.1007/978-81-322-1877-7_2

Mia MAB, Shamsuddin ZH, Wahab Z, Marziah M (2010). Effect of plant growth promoting rhizobacterial (PGPR) inoculation on growth and nitrogen incorporation of tissue-cultured Musa plantlets under nitrogen-free hydroponics condition. Australian Journal of Crop Science 4: 8590. [online] URL: http://search.informit.com. au/documentSummary; $d n=982523241783379$;re $s=$ IELHSS

Mimet A, Pellissier V, Quénol H, Aguejdad R, Dubreuil V, Rozé R (2009). Urbanisation induces early flowering: evidence from Platanus acerifolia and Prunus cerasus. International Journal of Biometeorology 53:287-298. - doi: 10.1007/s004 84-009-0214-7

Morina F, Jovanović LJ, Kukavica B, Veljović-Jovanović S (2008). Peroxidase, phenolics, and antioxidative capacity of common mullein (Verbascum thapsus L.) grown in a zinc excess. Archives of Biological Science 60: 687-695. - doi: 10.2298/ABSo804687M

Nautiyal CS (1999). An efficient microbiological growth medium for screening phosphate solubilizing microorganisms. FEMS Microbiology Letters 170: 265-270. - doi: 10.1111/j.1574-6968.19 99.tb13383.x

Panconesi A (1999). Canker stain of plane tree: a serious danger to urban plantings in Europe. Journal of Plant Pathology 81: 3-15.

Patten CL, Glick BR (2002). Role of Pseudomonas putida indoleacetic acid in development of the host plant root system. Applied and Environmental Microbiology 68: 3795-3801. - doi: 10.1128/AEM.68.8.3795-3801.2002

Pilotti M, Brunetti A, Tizzani L, Marani O (2009). Platanus $x$ acerifolia genotypes surviving to inoculation with Ceratocystis platani (the agent of canker stain): first screening and molecular characterization. Euphytica 169: 1-17. - doi: 10.10 07/s10681-009-9884-9

Pilotti M, Di Lernia G, Lumia V, Riccioni L (2014). Phytophthora cinnamomi causing stem canker and root rot of nursery grown Platanus $\times$ acerifolia: first report in the Northern emisphere. Phytopathologia Mediterranea 53: 75-82. - doi: 10.14601/Phytopathol_Mediterr-11836

Pilotti M, Di Lernia G, Modesti V, Lumia V, Brunetti A (2015). Outcome of Ceratocystis platani inoculations in Platanus $\times$ acerifolia in relation to season and inoculum dose. iForest 9 (4): 608-617. - doi: 10.3832/ifor1594-008

Ribeiro CM, Cardoso EJBN (2012). Isolation, selection and characterization of root-associated growth promoting bacteria in Brazil Pine (Araucaria angustifolia). Microbiological Research 167: 69-78. - doi: 10.1016/j.micres.2011.03.003 Ristović IM, Stojalović MP, Vulić M (2010). Recultivation and sustainable development of coal mining in Kolubara Basin. Thermal Science 14: 759-772. - doi: 10.2298/TSClo91123002R

Rodriguez-Barrueco CE, Cervantes NS, Subbarao NS, Rodriguez-Caceres E (1991). Growth promoting effect of Azospirillum brasilense on Casuarina cunninghamiana Miq. seedlings. Plant and Soil 135: 121-124. - doi: 10.1007/BFo0014784 Rojas-Tapias D, Moreno-Galván A, Pardo-Díaz S, Obando M, Rivera D, Bonilla R (2012). Effect of inoculation with plant growth-promoting bacteria (PGPB) on amelioration of saline stress in maize (Zea mays). Applied Soil Ecology 61: 264272. - doi: 10.1016/j.apsoil.2012.01.006

Rowell D (1994). Soil science: methods and application. Longman Scientific and Technical, London, UK, pp. 350.

Sharma PK, Fu J, Zhang X, Fristensky B, Sparling $R$, Levin DB (2014). Genome features of Pseudomonas putida LS46, a novel polyhydroxyalkanoate producer and its comparison with other P. putida strains. AMB Express 4: 1-18. - doi: 10.1186/2191-0855-4-1

Singh M, Prakash NT (2012). Characterisation of phosphate solubilising bacteria in sandy loam soil under chickpea cropping system. Indian Journal of Microbiology 52: 167-173. - doi: 10.1007/s12088-011-0209-Z

Singleton VL, Rossi JA (1965). Colorimetry of total phenolics with phosphomolybdic-phosphotungstic acid reagents. American Journal of Enology and Viticulture 16: 144-158. [online] URL: http://www.ajevonline.org/content/16/3/1 44.short

Skousen J, Zipper CE (2014). Post-mining policies and practices in the Eastern USA coal region. International Journal of Coal Science and Technology 1: 135-151. - doi: 10.1007/s40789-014-00216

Sousa NR, Franco AR, Ramos MA, Oliveira RS, Castro PML (2015). The response of Betula pubescens to inoculation with an ectomycorrhizal fungus and a plant growth promoting bacterium is substrate-dependent. Ecological Engineering 81: 439-443. - doi: 10.1016/j.ecoleng.20 15.04 .024

Tredici P (2007). Disturbance ecology and symbiosis in mine-reclamation design. In: "Designing the Reclaimed Landscape" (Berger A ed). Taylor and Francis, UK, pp. 13-25. [online] URL: http://books.google.com/books?id=UcuTAgAA 
QBAJ

Vidović M, Morina F, Milić S, Zechmann B, Albert A, Winkler JB, Veljović Jovanović S (2015). Ultraviolet-B component of sunlight stimulates photosynthesis and flavonoid accumulation in variegated Plectranthus coleoides leaves depending on background light. Plant, Cell and Environment 38: 968-979. - doi: 10.1111/pce.12471 Vigouroux A, Olivier R (2004). First hybrid plane trees to show resistance against canker stain (Ceratocystis fimbriata f. sp. platani). Forest Pathology 34: 307-319. - doi: 10.1111/j.1439-0329.20 04.00372.x

Whiteman SA, Stewart A (1998). Suppression of Botrytis cinerea sporulation on irradiated grape leaf tissues by the antagonistic bacterium Serratia liquefaciens. New Zealand Journal of Crop and Horticultural Science 26: 325-330. - doi:
10.1080/01140671.1998.9514071

Yamamoto S, Kasai H, Arnold DL, Jackson RW, Vivian A, Harayama S (2000). Phylogeny of the genus Pseudomonas: intrageneric structure reconstructed from the nucleotide sequences of gyrB and rpoD genes. Microbiology 146: $2385-$ 2394. - doi: 10.1099/00221287-146-10-2385 